\title{
Defence Heritage as a Cultural Heritage Tourism Resource: Case of Cyprus
}

\author{
Damla Mısırlısoy ${ }^{1 *}$ Kağan Günçe ${ }^{2}$ \\ ${ }^{1}$ Faculty of Architecture, European University of Lefke, Lefke, Mersin 10 Turkey, Northern, Cyprus \\ ${ }^{2}$ Faculty of Architecture, Eastern Mediterranean University, Famagusta, Mersin 10 Turkey, Northern, Cyprus
}

Corresponding Author Email: dmisirlisoy@eul.edu.tr

https://doi.org/10.18280/ijsdp.160414

Received: 19 February 2021

Accepted: 8 May 2021

\section{Keywords:}

defence heritage, conservation, adaptive reuse, cultural heritage, cultural heritage tourism, Cyprus

\begin{abstract}
Cyprus has one of the richest histories of Europe and the Middle East. As the result of being an island and having a strategic location, Cyprus had been occupied by different civilizations throughout history. Since the island faced many attacks throughout history, different buildings and structures were built to defend the island from its enemies. Defence heritage should be identified, documented and conserved since they are important part of the collective memory of the island. The only way to sustain these monuments is to reuse with an appropriate function since they have already lost their original function. The purpose of the study is to highlight the significance of defence heritage of the island and propose reuse strategies as a cultural tourism resource. The method of the study to includes literature surveys and observations through site survey. These data are used for developing reuse strategies by considering defence heritage as a cultural heritage tourism resource. Defence heritage structures can be used as tool for contributing cultural tourism of the island. Defence heritage is an important part of cultural heritage; therefore, they should be transferred for further generations through conservation and reuse.
\end{abstract}

\section{INTRODUCTION}

The conservation of defence heritage structures is important since they are monuments that represent a sense of identity, national pride and bearing a message of oppression. In this respect, it is important to transfer these structures for further generations through conservation and reuse. Defence heritage structures should conserved and reused with different functions since they lost their original function. In order to preserve heritage buildings and transfer them to future generations, adaptive reuse is inevitable [1]. The conservation and adaptive reuse of heritage buildings through social consciousness also ensures social and cultural sustainability [2].

Defence heritage includes any building and structure that built to protect the city or country from its enemies. Defence heritage can be categorized differently in various sources. However, in this study, the following classification has been used: fortifications, castles and observation towers [3].

Defence artefacts have tendency to survive better than most historic structures and objects due to their construction purposes. Also, these structures give us clues about the culture, construction system and history of defence system of the related community. In this respect, defence heritage structures have potential to be reused to contribute cultural tourism. The appropriately reused defence heritage buildings for cultural tourism purposes become one of the mostly visited cultural heritage assets of the city.

Cultural heritage is one of most important resources of international tourism since the places and structures related to war, are one of the important components of heritage and there is a growing demand for tourist visits [4]. Defence heritage structures, which have managed to survive until today, are usually used with different functions rather than their original uses [5]. The adaptation of heritage buildings to new uses, especially, defence heritage buildings, is a process that needs different technical tools [6].

As a Mediterranean island, Cyprus structured its economy to the tourism industry for the last three decades. In this respect, tourism has an important role in its economic development and also, its relationships with the other countries [7]. Defence heritage is a crucial part of the architectural heritage of the island that should be reused as a cultural heritage tourism resource. The purpose of the study is to highlight the significance of defence heritage of the island and propose reuse strategies as a cultural tourism resource.

\section{METHODOLOGY}

The method of the study to includes literature surveys, observations through site survey and classification of the defence heritage of the island. Firstly, literature surveys were completed in order to find out the number of defence heritage sites and their location. Secondly, defence heritage buildings and structures have been visited in order to observe, document the current condition and classify them according to their location. Through site surveys, it is observed whether the defence heritage sites still exist today or demolished, the physical condition and current use. Then, Table 1 is prepared to represent the collected data.

Finally, the data is used to develop adaptive reuse strategies by considering defence heritage as a cultural heritage tourism resource. Data obtained through literature survey is used to 
develop strategies for reusing defence heritage as cultural heritage tourism resource.

\section{CULTURAL HERITAGE TOURISM}

Cultural heritage is one of the most significant tourism resources in the world and many places look to the cultural heritage for their socio-economic development through tourism [8]. Heritage tourism can be accepted as a branch or sub-niche of cultural tourism [9] and it is one of the most important and widespread types of tourism and is among the very oldest forms of travel [10].

Cultural heritage assets have the potential to attract people from different societies due to their heritage values. Since they are the witnesses of the historic periods, they become valuable places to be visited as a tourism resource. "Heritage tourism refers to travellers seeing or experiencing built heritage, living culture or contemporary arts. Its resources are tangible and intangible and found both in rural and urban settings. Visits are motivated by a desire to enhance one's own cultural self, to learn something new, to spend time with friends and family, to satisfy one's curiosity or simply to use up excess time. In short, heritage tourism encompasses a multitude of motives, resources and experiences and is different for every individual and every place visited" [11].

Tourism sector has become popular especially in the $20^{\text {th }}$ century with the effect of cultural tourism. Before $20^{\text {th }}$ century, tourism was used just as a tool for national development; however, today it is accepted as the promoter of regional, local and urban development. In this respect, the goal becomes the contribution of cultural tourism in regional scale instead of urban scale [12]. After the development in the world tourism in the late $20^{\text {th }}$ century, cultural heritage become an important economic resource [13]. Today, experts in tourism sector see cultural heritage as a resource that should be developed [14]. Tourism became one the most powerful economic, social, cultural, ecological and political forces [10].

Cultural heritage tourism helps to protect cultural heritage and to improve the quality of life of residents and visitors. Relating cultural heritage with tourism benefits the local economy. The main aim in cultural heritage tourism is to save urban heritage and culture, to share it with visitors, and to reach economic benefits [15].

In heritage tourism, visitors play a significant role [16]. Visitors' personal connections with cultural artefacts influence the quality of heritage tourism experiences [17]. However, the number of visitors in the cultural heritage assets should be controlled. Over-use and under-use of the heritage can be accepted as a threat to the sustainability of cultural tourism products. While over-use can damage the physical fabric of the heritage, damage tangible and intangible values, under-use can result in the lack of support for needed conservation work or a loss of local support for maintaining the attraction [18].

1.Stakeholders' values and objectives

2.Morphological characteristics of cultural heritage assets

3.Accessibility and functionality

4.Integration with other tourism activities and supporting elements

A cultural tourism product therefore needs to be developed, from its original form instead of designing it to satisfy tourists' needs. The asset should be transformed and developed into a product that can be explicitly consumed by tourists [19]. The key factors influencing the success of the product development in cultural tourism can be identified as [20].

Cultural heritage has two major types as the tangible and the intangible. Tangible cultural heritage includes historic cities, cultural landscapes, monuments, sculptures, etc. [21]. On the other hand, intangible cultural heritage as non-physical values include folklore, beliefs, traditions, language, knowledge, etc. Both intangible and tangible cultural heritage can be used as cultural heritage tourism resource. Heritage tourism can be defined as visits or experiences of both tangible and intangible evidences of the past [22]. The neglect of the potential of cultural heritage as a tourism resource can be result as missing the opportunities for economic and social development and also, can result in the disappearance of certain cultural values such as national identity and pride [7]

\section{DEFENCE HERITAGE OF CYPRUS}

\subsection{Defence history of the island}

Cyprus is the third largest island in the Mediterranean Sea. It occupies a key position in the Eastern Mediterranean [23]. Cyprus has one of the richest and most fascinating histories of Europe and the Middle East. As the result of being an island and having a strategic location, Cyprus had been occupied by different civilizations throughout history. This demographic composition of Cyprus is the result of its long and turbulent history. Cyprus became a focus of interest between various people and states of different cultures and religions because of its geographical location and strategic importance. These civilizations include: Byzantines (395-1191), Lusignans (1192-1489), Venetians (1489-1571), Ottomans (1571-1878), and British (1878-1960) [24].

Major developments regarding with the defence heritage of Cyprus took place especially Lusignan and Venetian periods. Fortifications and castles were built to defence the cities from the attacks.

In 1974, the island was divided into two sectors as: The Northern Cyprus where Turkish Cypriots live and the Southern Cyprus where Greek Cypriots live. The division and the political issues continue to present a major problem, which affects the conservation of heritage sites regardless of the identity of the owners whether Turkish Cypriot or Greek Cypriot.

Many cultures have lived on the island and following every period of occupation, the island has changed its socioeconomic and socio-cultural structure. In this respect, multiculturality is the most important aspect in the architecture of Cyprus. The island has successfully preserved its rich cultural heritage, despite changes in its socio-economic, economic and political structure. Despite the changing societal mosaic on the island, traditional architectural traces can still be found [25]. The architecture of the island has been affected by all of these factors. Since the island faced many attacks throughout history, different defence structures were built to protect the island from its enemies. In this respect, these structures are important elements of the architectural heritage of the island (Figure 1).

Defence heritage of the island includes castles, fortifications and observation towers. Totally, there are 3 fortifications, 12 castles and 5 observation towers located in different parts of the island (Figure 1). There are five more castles in Cyprus that it is known named as Khirokitia, Yermasoyia, Gastria, 
Sigouri and Potamia, which were lost long ago and there are no traces of the structures. In this respect, they are beyond the scope of the study.

Kouklia is not also mentioned in the study since it does not have defensive purpose but functioned as palaces. Kouklia was not a fortification but rather a manorial complex, the purpose and function of which was primarily economic. It was built as a centre for the administration of royal estates [26].

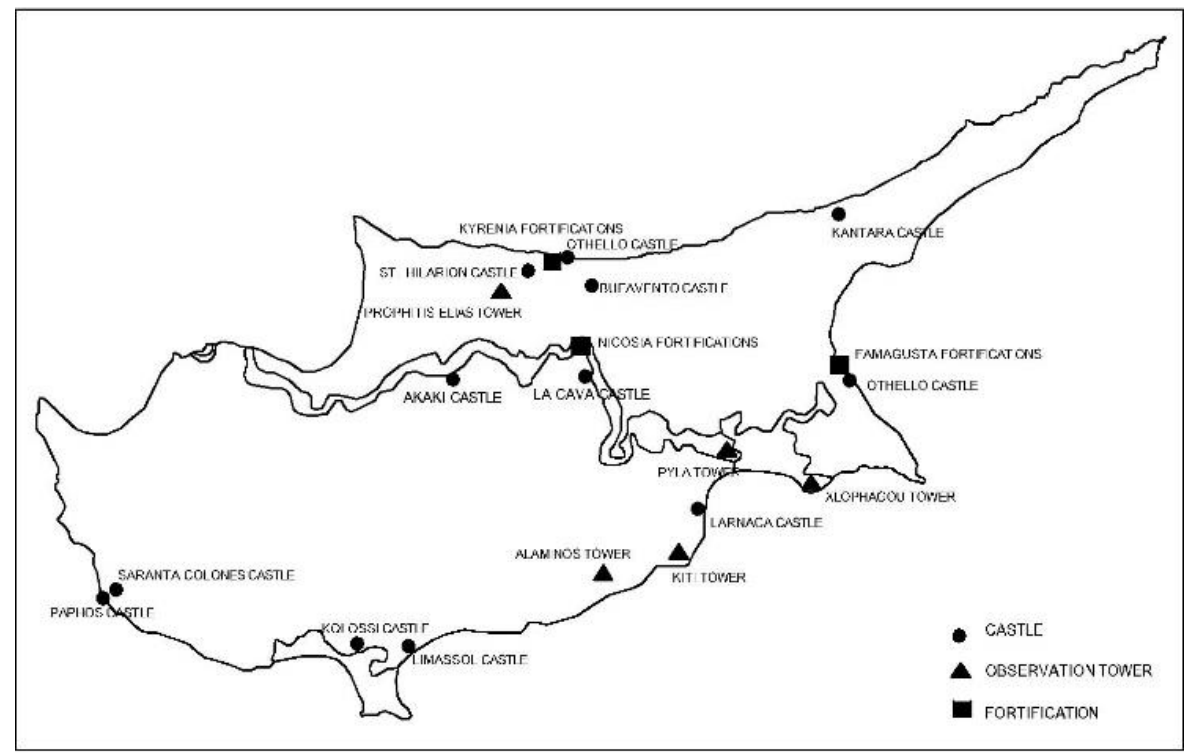

Figure 1. Location of the castles of Cyprus (Developed by authors according to Petre [26])

\subsection{Classification of defence heritage of Cyprus}

Defence heritage of Cyprus can be classified as fortifications, castles and observation towers. Castles are complex structures that are used for defensive and administrative purpose. Mostly, castles also provide a residence for the king, his family and their servants. Fortifications can be defined as walls and structures that are built around a city or region for defensive purposes. Sometimes they are combined with the castles. Castles and fortifications are evidence of the former social structure, the state's economy and the culture [26]. Observation towers are the structures that have been built mostly on top of mountains or next to the sea in order to observe enemies approaching towards the land. They can be constructed attached to a castle or they can also be freestanding structures.

\subsubsection{Fortifications}

Fortification can be defined as the defensive wall built to strengthen the city or town against attack. The main aim of the fortifications is protection and defence purposes. It is a physical border between the city and the inner land or sea and includes various gates in different points that ensure access to the city.

Defence fortifications were built to protect towns and their residents or sites from potential enemy attacks. The fundamental assumption was that defensive walls would not only be resistant to environmental elements but also to military action aimed at purposeful destruction, employing military equipment. That is why the structures built were massive, durable and able to withstand various types of loading, even extraordinary loading [5]. The defence heritage of island includes three fortifications located different cites, which all of them remained in the northern part of the island after the division (Figure 2). Two of these fortifications exist today; however, one of them had been demolished and only three towers of the fortifications had been managed to survive until today.

\subsubsection{Castles}

Castles can be defined as a large building or group of buildings fortified against attacks with thick walls, battlements, towers, and in many cases a moat. There are some examples that castles are attached to the city walls.

Totally, there are 12 castles on the island (Figure 3); five of the listed castles (St. Hilarion, Bufavento, Kantara, Kyrenia and Othello) lie in the northern part, while six (Kolossi, Larnaca, Limassol, Paphos, Saranta Colones, La Cava and Akaki) are in the southern part of the island.

\subsubsection{Observation Towers}

Observation towers are another important elements of defence heritage of the island. They are usually tall and narrow structures used to watch enemies approaching to the towns from a long distance. Totally, there are five observation towers located on the island (Figure 4). The four of them remained in the Southern part of the island; however only one of them is in the Northern part.

According to the analysis, mainly, there is three different types according to the location of the defence heritage structures within the city: castles located near seacoast, located on the mountains and located on the inner land of the city. There are some examples where the castle located next to the sea, sometimes attached to city fortifications, which protect the city, or sometime they appear as single building scale without any fortification close to the castle. On the other hand, castles located on the mountains, were built to protect themselves from attacks. There are two types in this category: attached to city fortifications which protects the city or they appear as single building scale without any fortification close to the castle. Also, there are some examples that are located on the inner land of the city. And this category can be divided into two as the ones located in the rural context and ones in the city or town centre (Figure 5). 


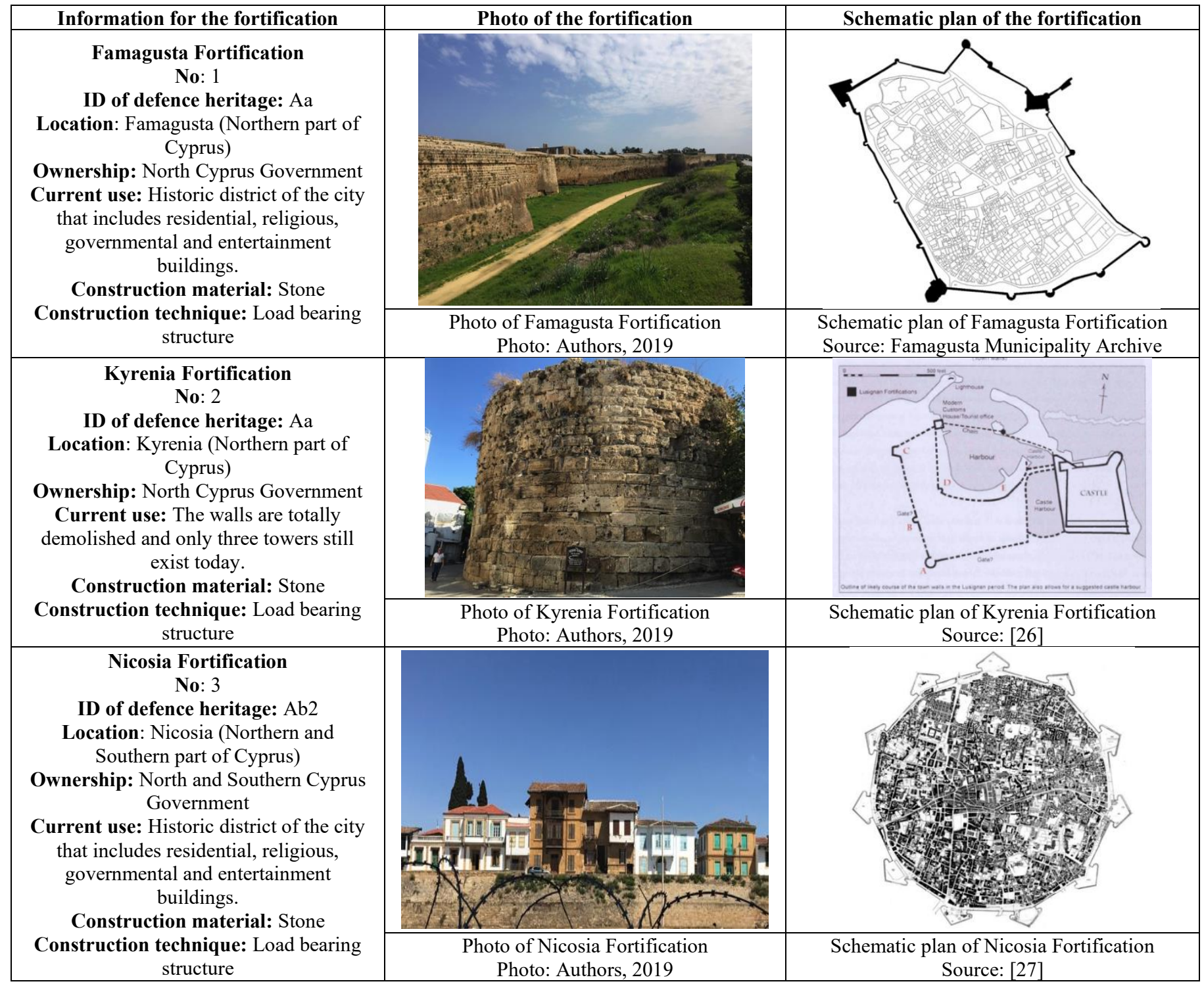

Figure 2. Fortifications in Cyprus

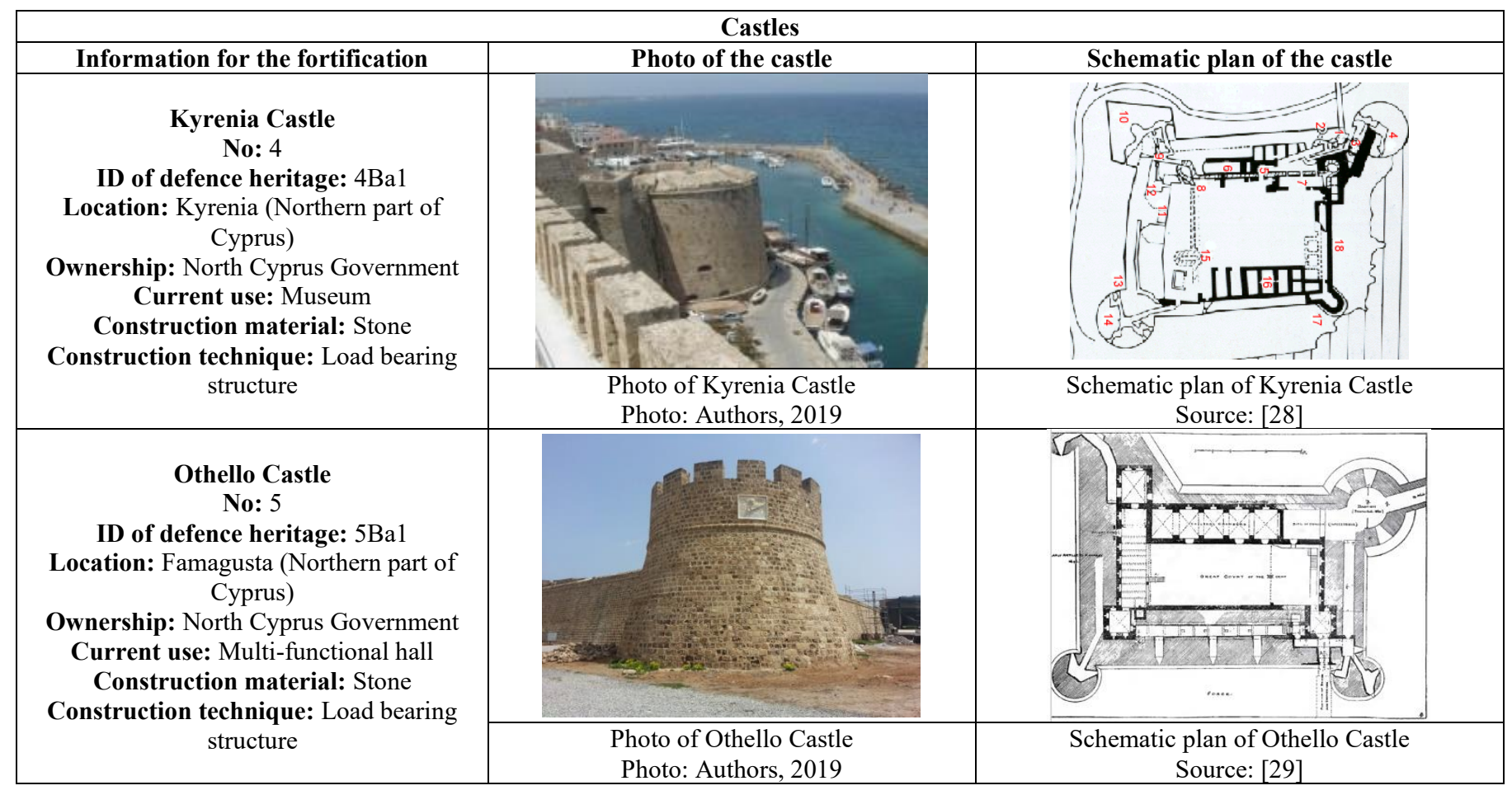




\begin{tabular}{|c|c|c|}
\hline \multirow[t]{2}{*}{$\begin{array}{c}\text { Paphos Castle } \\
\text { No: } 6 \\
\text { ID of defence heritage: } 6 \mathrm{Ba} 2 \\
\text { Location: Paphos (Southern part of } \\
\text { Cyprus) } \\
\text { Ownership: South Cyprus Government } \\
\text { Current use: Exhibition hall } \\
\text { Construction material: Stone } \\
\text { Construction technique: Load bearing } \\
\text { structure }\end{array}$} & & \multirow[b]{2}{*}{$\begin{array}{l}\text { Schematic plan of Paphos Castle } \\
\text { Source: [26] }\end{array}$} \\
\hline & $\begin{array}{l}\text { Photo of Paphos Castle } \\
\text { Photo: Authors, } 2019\end{array}$ & \\
\hline \multirow[t]{2}{*}{$\begin{array}{c}\text { Larnaca Castle } \\
\text { No: } 7 \\
\text { ID of defence heritage: } 7 \mathrm{Ba} 2 \\
\text { Location: Larnaca (Southern part of } \\
\text { Cyprus) } \\
\text { Ownership: South Cyprus Government } \\
\text { Current use: Museum } \\
\text { Construction material: Stone } \\
\text { Construction technique: Load bearing } \\
\text { structure }\end{array}$} & & $\begin{array}{ll} & 1 \\
1 & 1\end{array}$ \\
\hline & $\begin{array}{l}\text { Photo of Larnaca Castle } \\
\text { Photo: Authors, } 2019 \\
\end{array}$ & $\begin{array}{c}\text { Schematic plan of Larnaca Castle } \\
\text { Source: [30] }\end{array}$ \\
\hline \multirow[t]{2}{*}{$\begin{array}{c}\text { Saint Hilarion Castle } \\
\text { No: } 8 \\
\text { ID of defence heritage: } 8 \mathrm{Bb} 1 \mathrm{x} \\
\text { Location: Kyrenia (Northern part of } \\
\text { Cyprus) } \\
\text { Ownership: North Cyprus Government } \\
\text { Current use: Museum } \\
\text { Construction material: Stone } \\
\text { Construction technique: Load bearing } \\
\text { structure }\end{array}$} & & \multirow[b]{2}{*}{$\begin{array}{l}\text { Schematic plan of St. Hilarion Castle } \\
\text { Source: [29] }\end{array}$} \\
\hline & $\begin{array}{l}\text { Photo of Saint Hilarion Castle } \\
\text { Photo: Authors, } 2019\end{array}$ & \\
\hline \multirow[t]{2}{*}{$\begin{array}{c}\text { Kantara Castle } \\
\text { No: } 9 \\
\text { ID of defence heritage: } 9 \mathrm{Bb} 1 \mathrm{x} \\
\text { Location: Yeni İskele (Northern part of } \\
\text { Cyprus) } \\
\text { Ownership: North Cyprus Government } \\
\text { Current use: Historic ruin for visitors } \\
\text { Construction material: Stone } \\
\text { Construction technique: Load bearing } \\
\text { structure }\end{array}$} & & \multirow{2}{*}{$\begin{array}{l}\text { Schematic plan of Kantara Castle } \\
\text { Source: [31] }\end{array}$} \\
\hline & $\begin{array}{l}\text { Photo of Kantara Castle } \\
\text { Photo: Authors, } 2019 \\
\end{array}$ & \\
\hline \multirow[t]{2}{*}{$\begin{array}{c}\text { Bufavento Castle } \\
\text { No: } 10 \\
\text { ID of defence heritage: } 10 \mathrm{Bb} 1 \mathrm{q} \\
\text { Location: Kyrenia (Northern part of } \\
\text { Cyprus) } \\
\text { Ownership: North Cyprus Government } \\
\text { Current use: Historic ruin for visitors } \\
\text { Construction material: Stone } \\
\text { Construction technique: Load bearing } \\
\text { structure }\end{array}$} & & (3] \\
\hline & $\begin{array}{l}\text { Photo of Bufavento Castle } \\
\text { Photo: Authors, } 2019 \\
\end{array}$ & $\begin{array}{c}\text { Schematic plan of Bufavento Castle } \\
\text { Source: }[28]\end{array}$ \\
\hline \multirow[t]{2}{*}{$\begin{array}{c}\text { Kolossi Castle } \\
\text { No: } 11 \\
\text { ID of defence heritage: } 11 \mathrm{Bb} 2 \mathrm{q} \\
\text { Location: Limassol (Southern part of } \\
\text { Cyprus) } \\
\text { Ownership: South Cyprus Government } \\
\text { Current use: Historic ruin for visitors } \\
\text { Construction material: Stone } \\
\text { Construction technique: Load bearing } \\
\text { structure }\end{array}$} & $\because$ & $\stackrel{\oplus=}{\stackrel{D}{=}}$ \\
\hline & $\begin{array}{l}\text { Photo of Kolossi Castle } \\
\text { Photo: Authors, } 2019 \\
\end{array}$ & $\begin{array}{l}\text { Schematic plan of Kolossi Castle } \\
\text { Source: Kolossi C. Exhibition Panels }\end{array}$ \\
\hline
\end{tabular}




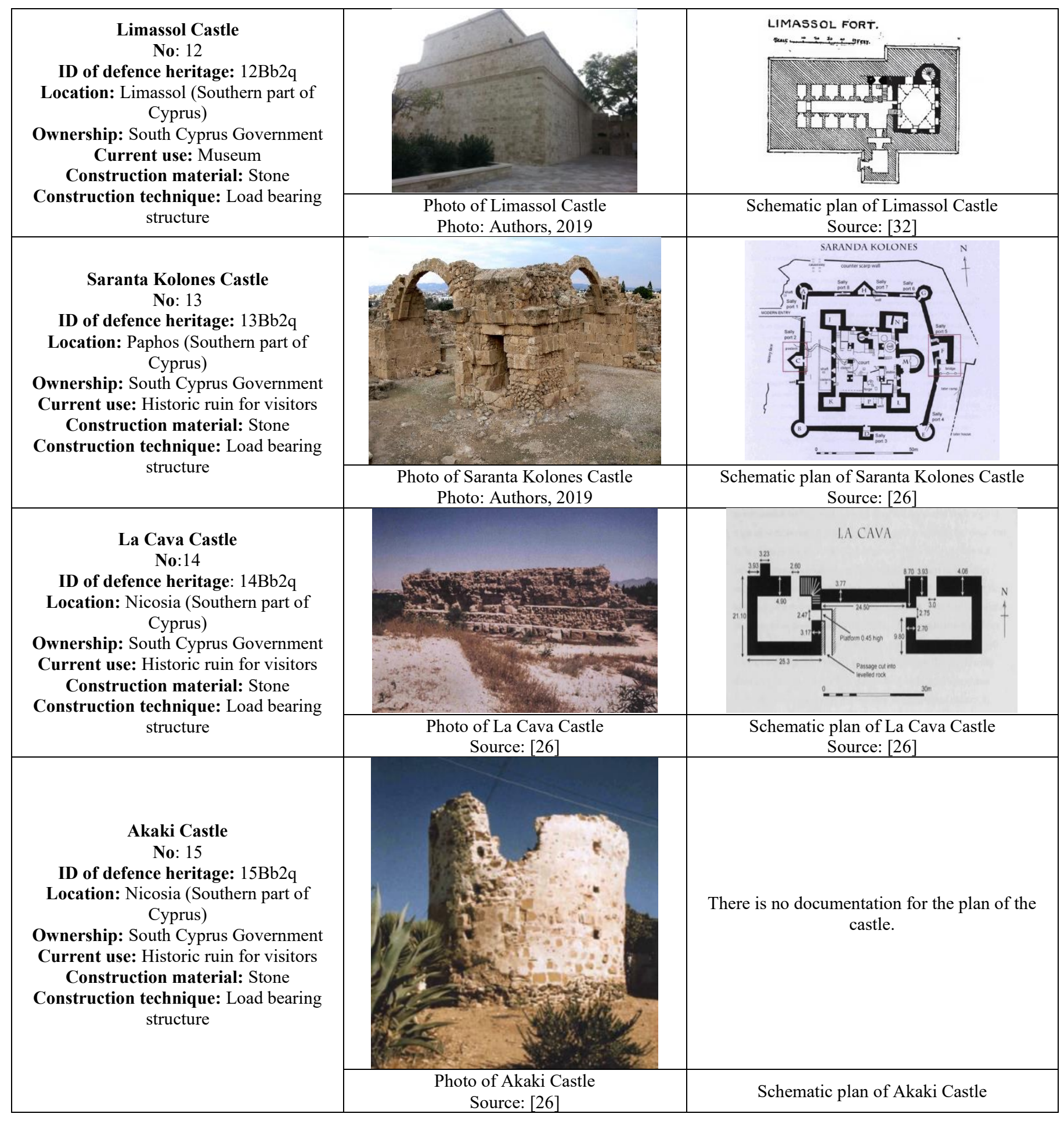

Figure 3. Castles in Cyprus

\begin{tabular}{|c|c|c|}
\hline \multicolumn{3}{|c|}{ Observation towers } \\
\hline Information for the tower & Photo of the tower & Plan of the tower \\
\hline $\begin{array}{l}\text { Prophitis Elias Observation Tower } \\
\text { No: } 16 \\
\text { ID of defence heritage: } 16 \mathrm{Cb} 1 \\
\text { Location: Kyrenia (Northern part of } \\
\text { Cyprus) } \\
\text { Ownership: North Cyprus Government } \\
\text { Current use: Historic ruin for visitors } \\
\text { Construction material: Stone } \\
\text { Construction technique: Load bearing }\end{array}$ & 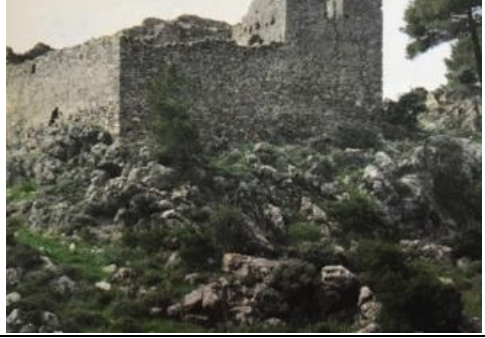 & $-\cdots$ \\
\hline structure & $\begin{array}{l}\text { Photo of Prophitis Elias Obs. Tower } \\
\text { Photo: [33] }\end{array}$ & $\begin{array}{c}\text { Schematic plan of Prophitis Elias Tower } \\
\text { Source: Drawn by Authors }\end{array}$ \\
\hline
\end{tabular}




\begin{tabular}{|c|c|c|}
\hline \multirow[t]{2}{*}{$\begin{array}{l}\text { Xylofagou Observation Tower } \\
\text { No: } 17 \\
\text { ID of defence heritage: } 17 \mathrm{Ca} \\
\text { Location: Larnaca (Southern part of } \\
\text { Cyprus) } \\
\text { Ownership: South Cyprus Government } \\
\text { Current use: Historic ruin for visitors } \\
\text { Construction material: Stone } \\
\text { Construction technique: Load bearing } \\
\text { structure }\end{array}$} & 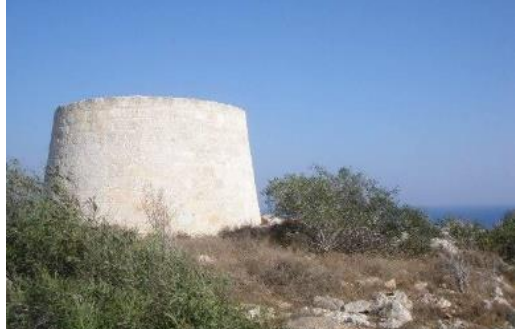 & 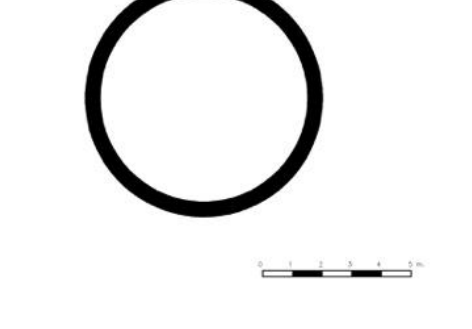 \\
\hline & $\begin{array}{c}\text { Photo of Xylofagou Obs. Tower } \\
\text { Photo: [34] }\end{array}$ & $\begin{array}{c}\text { Schematic plan of Xylofagou Tower } \\
\text { Source: Drawn by Authors }\end{array}$ \\
\hline \multirow[t]{2}{*}{$\begin{array}{l}\text { Pyla Observation Tower } \\
\text { No: } 18 \\
\text { ID of defence heritage: } 18 \mathrm{Ca} \\
\text { Location: Larnaca (Southern part of } \\
\text { Cyprus) } \\
\text { Ownership: South Cyprus Government } \\
\text { Current use: Historic ruin for visitors } \\
\text { Construction material: Stone } \\
\text { Construction technique: Load bearing } \\
\text { structure }\end{array}$} & 15 & 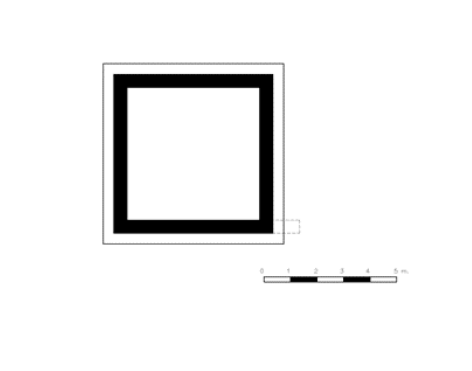 \\
\hline & $\begin{array}{c}\text { Photo of Pyla Observation Tower } \\
\text { Source: [6] }\end{array}$ & $\begin{array}{c}\text { Schematic plan of Pyla Obs. Tower } \\
\text { Source: Drawn by Authors }\end{array}$ \\
\hline \multirow[t]{2}{*}{$\begin{array}{l}\text { Perivolia/Kiti Observation Tower } \\
\text { No: } 19 \\
\text { ID of defence heritage: } 19 \mathrm{Cb} 2 \\
\text { Location: Larnaca (Southern part of } \\
\text { Cyprus) } \\
\text { Ownership: South Cyprus Government } \\
\text { Current use: Historic ruin for visitors } \\
\text { Construction material: Stone } \\
\text { Construction technique: Load bearing } \\
\text { structure }\end{array}$} & 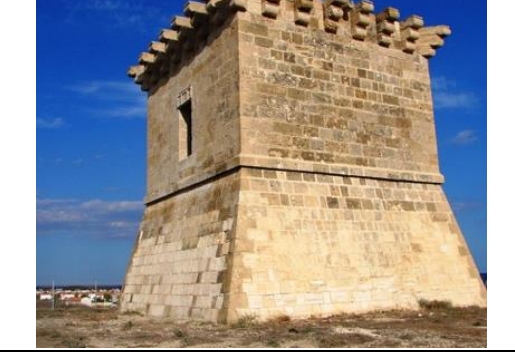 & $=-$ \\
\hline & $\begin{array}{l}\text { Photo of Perivolia/Kiti Obs. Tower } \\
\text { Photo: [35] }\end{array}$ & $\begin{array}{l}\text { Schematic plan of Perivolia/Kiti } \\
\text { Source: Drawn by Authors }\end{array}$ \\
\hline \multirow[t]{2}{*}{$\begin{array}{l}\text { Alaminyos Observation Tower } \\
\text { No: } 20 \\
\text { ID of defence heritage: } 20 \mathrm{Cb} 2 \\
\text { Location: Larnaca (Southern part of } \\
\text { Cyprus) } \\
\text { Ownership: South Cyprus Government } \\
\text { Current use: Historic ruin for visitors } \\
\text { Construction material: Stone } \\
\text { Construction technique: Load bearing } \\
\text { structure }\end{array}$} & & 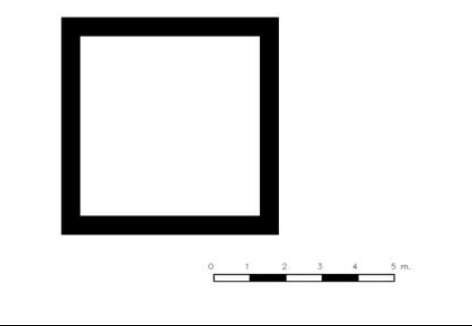 \\
\hline & $\begin{array}{l}\text { Photo of Alaminyos Observation Tower } \\
\text { Source: [26] }\end{array}$ & $\begin{array}{c}\text { Schematic plan of Alaminyos Tower } \\
\text { Source: Drawn by Authors }\end{array}$ \\
\hline
\end{tabular}

Figure 4. Observation towers in Cyprus

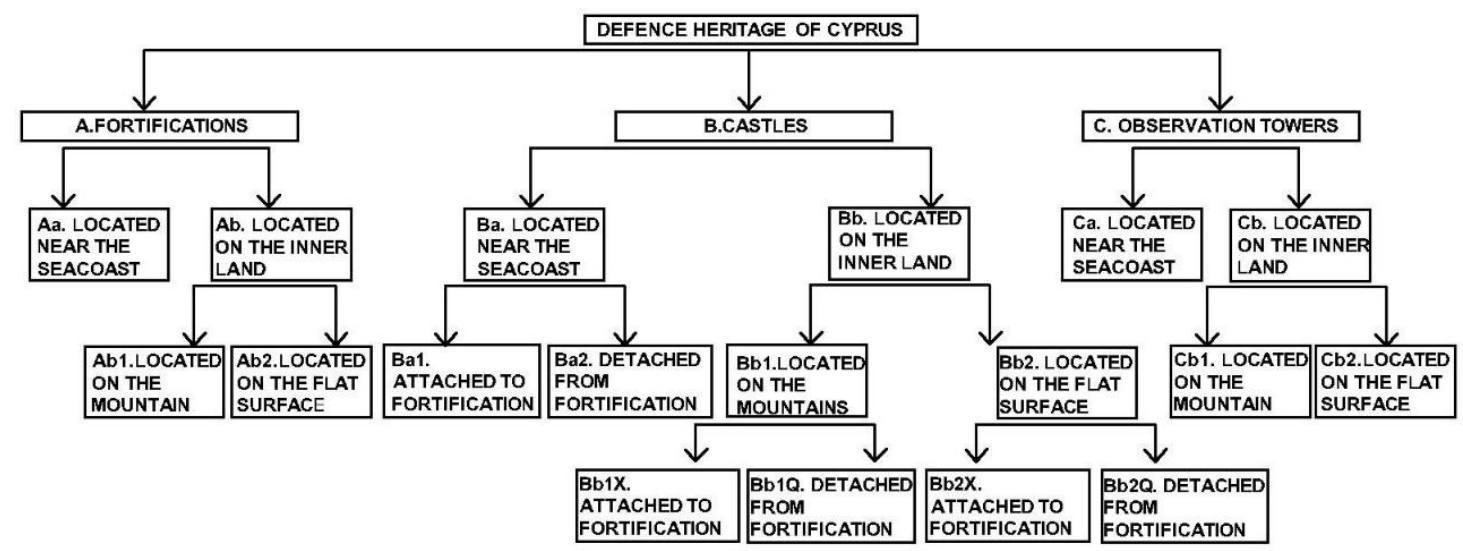

Figure 5. Classification of defence heritage of Cyprus 


\section{STRATEGIES FOR REUSING DEFENCE HERITAGE AS A CULTURAL HERITAGE TOURISM RESOURCE}

Defence heritage is an important part of the cultural heritage and therefore these structures need to be sustained through refunctioning. The significance of the research is to examine the issue with a holistic approach. As a result of the collected data, there are five important factors that should be considered for the reuse of defence heritage through cultural heritage tourism as explained below:

Rethinking defence heritage with a holistic approach: Defence heritage structures should be reused with a holistic approach in a way that contributes cultural tourism of the island. In a defence heritage building general information should be given for all defence heritage structures since they are a part of a whole defence system. A visitor should have information about history, process and conservation of all defence heritage buildings of Cyprus.

Collaboration: Division of the island is the biggest problem in terms of conservation of heritage buildings. The conservation of cultural heritage has been used as a tool to establishing peace between the two communities in Cyprus. If the reunion of the island took place in the future, a common conservation strategy should be prepared between two communities for defence heritage building and structures. Also, general information should be given about the history of the island and how defence heritage structures affected during the process.

Balancing number and types of users: In order to achieve sustainable cultural heritage tourism, the number and the types of users should be balanced. The needs of the local people should be considered as well as expectation of visitors and tourists. It is important to ensure that cultural heritage tourism benefits everyone. Over-use and under-use of the heritage can be accepted as a threat to the sustainability of cultural tourism products. While over-use can damage the physical fabric of the heritage, damage tangible and intangible values, under-use can result in the lack of support for needed conservation work or a loss of local support for maintaining the attraction.

Focusing authenticity: Defence heritage buildings should be conserved in order to maintain the authenticity. The authenticity that is unique should add value to visitor. The history and culture is interesting for visitor, since it distinguishes the place from other places in the world.

Preparing management plans: As discussed before only way to sustain defence heritage buildings should be using them with a totally new use since they lost their original function. For the sustainability of the defence heritage, management plans should be prepared by the experts. In many adaptive reuse projects there are problems in management approaches to the heritage buildings. The preserved buildings should make their profits for the maintenance and rehabilitation works of the structures in the future. There is lack of existence of proper management plans and strategies for sustainable heritage adaptation. The main aim should be preserving the values and originality of the building and its context; however, the economic sustainability of the building is important for the future of the built heritage.

Table 1 is prepared to propose adaptive reuse strategies for defence heritage buildings in Cyprus as a cultural heritage tourism resource in the light of the discussed strategies. In the Table 1, location, type, physical condition and current function of the 20 defence heritage buildings or sites is identified. Then, new use proposals are discussed on how to use defence heritage as a source to contribute cultural heritage tourism of the island.

Table 1. New proposals for defence heritage structures of Cyprus

\begin{tabular}{|c|c|c|c|c|c|c|}
\hline \multicolumn{7}{|c|}{ DEFENCE HERITAGE OF CYPRUS } \\
\hline & Name & City & Type & $\begin{array}{l}\text { Physical } \\
\text { condition }\end{array}$ & $\begin{array}{l}\text { Current } \\
\text { function }\end{array}$ & New Use Proposals \\
\hline 1 & $\begin{array}{l}\text { Famagusta } \\
\text { Fortifications }\end{array}$ & $\begin{array}{l}\text { Famagusta, } \\
\text { North } \\
\text { Cyprus }\end{array}$ & $\mathrm{Aa}$ & $\begin{array}{l}\text { Needs } \\
\text { emergency } \\
\text { intervention }\end{array}$ & $\begin{array}{l}\text { Walls of the } \\
\text { city }\end{array}$ & $\begin{array}{l}\text { Spaces within the walls and bastions can be used as museums in Famagusta } \\
\text { fortifications. The moat around the walls can be used for sport and } \\
\text { recreational facilities. Walking routes can be proposed and different historic } \\
\text { city observation points can be created along the route. }\end{array}$ \\
\hline 2 & $\begin{array}{l}\text { Kyrenia } \\
\text { Fortifications }\end{array}$ & $\begin{array}{l}\text { Kyrenia, } \\
\text { North } \\
\text { Cyprus }\end{array}$ & $\mathrm{Aa}$ & $\begin{array}{c}\text { Partly } \\
\text { demolished }\end{array}$ & Demolished & $\begin{array}{l}\text { Kyrenia fortifications can be reconstructed or digital vitalization can be } \\
\text { applied together with the three towers that managed to survive. }\end{array}$ \\
\hline 3 & $\begin{array}{l}\text { Nicosia } \\
\text { Fortifications }\end{array}$ & $\begin{array}{l}\text { Nicosia, } \\
\text { North } \\
\text { Cyprus }\end{array}$ & $\mathrm{Ab} 2$ & $\begin{array}{l}\text { Needs } \\
\text { emergency } \\
\text { intervention }\end{array}$ & $\begin{array}{l}\text { Walls of the } \\
\text { city }\end{array}$ & $\begin{array}{l}\text { The city walls include } 11 \text { bastions and } 3 \text { gates that provide access to the city. } \\
11 \text { bastions can be used public spaces for social activities. The gates and the } \\
\text { spaces within the gates are tourist information centres and can be used for } \\
\text { cultural purpose. The moat around the walls can be used for sport and } \\
\text { recreational facilities. Walking routes can be proposed and different historic } \\
\text { city observation points can be created along the route. }\end{array}$ \\
\hline 4 & $\begin{array}{l}\text { Kyrenia } \\
\text { Castle }\end{array}$ & $\begin{array}{l}\text { Kyrenia, } \\
\text { North } \\
\text { Cyprus }\end{array}$ & Bal & Renovated & Museum & $\begin{array}{l}\text { Kyrenia castle located next to the demolished city walls and already re } \\
\text { functioned as museum; however, does not take enough attraction of the } \\
\text { visitors. The connection between the harbour and the castle should be } \\
\text { provided. The yard can be used for open-air activities such as theatre, } \\
\text { exhibition and concerts. }\end{array}$ \\
\hline 5 & $\begin{array}{l}\text { Othello } \\
\text { Castle }\end{array}$ & $\begin{array}{l}\text { Famagusta, } \\
\text { North } \\
\text { Cyprus }\end{array}$ & Ba1 & $\begin{array}{l}\text { Under } \\
\text { renovation }\end{array}$ & $\begin{array}{l}\text { Art and } \\
\text { cultural } \\
\text { center }\end{array}$ & $\begin{array}{l}\text { Othello castle located next to the city walls on the seacoast. In this respect, } \\
\text { the castle should be reused in relation with the historic city. Spaces within the } \\
\text { towers can be used as exhibition spaces. The courtyard can be used for open- } \\
\text { air activities such as theatre, exhibition and concerts. }\end{array}$ \\
\hline 6 & Paphos Castle & $\begin{array}{l}\text { Paphos, } \\
\text { South } \\
\text { Cyprus }\end{array}$ & $\mathrm{Ba} 2$ & Renovated & $\begin{array}{l}\text { Cultural } \\
\text { activity } \\
\text { centre }\end{array}$ & $\begin{array}{l}\text { Already refunctioned as cultural activity centre and it is used for different } \\
\text { social and cultural activities. There is a strong connection between indoor and } \\
\text { outdoor spaces of the castle. Different events such as theatre and concert are } \\
\text { organized in and around the castle. The castle can be continued to be used for } \\
\text { these kinds of activities. }\end{array}$ \\
\hline 7 & $\begin{array}{l}\text { Larnaca } \\
\text { Castle }\end{array}$ & $\begin{array}{l}\text { Larnaca, } \\
\text { South } \\
\text { Cyprus }\end{array}$ & $\mathrm{Ba} 2$ & Renovated & Museum & $\begin{array}{l}\text { Already refunctioned as a museum. However, the museum is not effectively } \\
\text { used and does not have a connection with the city. Social and cultural } \\
\text { activities can be organized in the courtyard. The towers of the castle can be }\end{array}$ \\
\hline
\end{tabular}




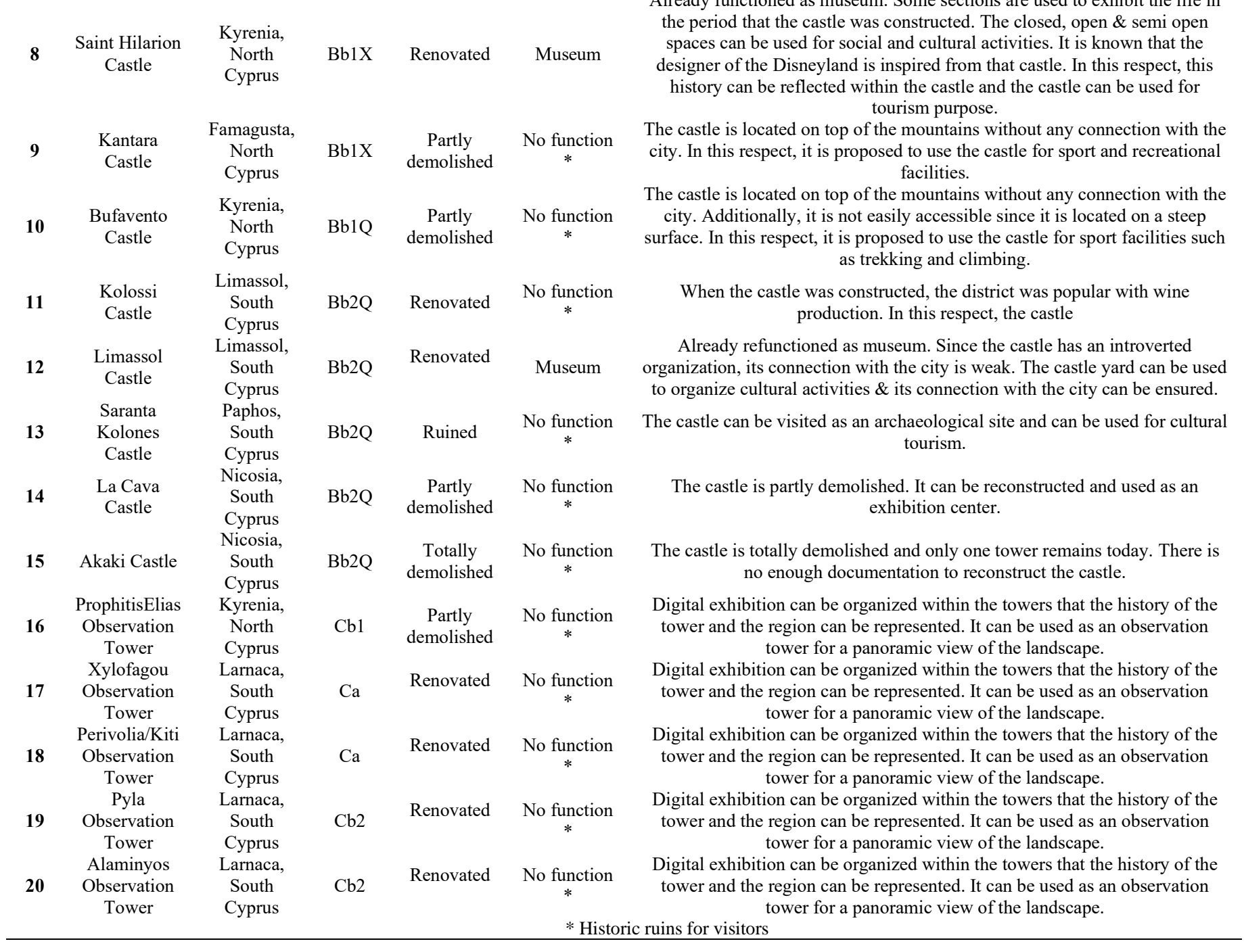

\section{CONCLUSION}

The conservation of defence heritage is crucial since they are monuments that represent a sense of identity, national pride and bearing a message of oppression. 20 defence heritage structure is identified, classified and new use strategies were developed to use them as a cultural heritage tourism resource.

It is observed through analysis that defence heritage structures are ignored, most of them need emergency measures and there are no enough studies regarding to the conservation and restoration of them. Since defence heritage buildings already lost their original function, only way to sustain them is re-functioning and reusing with different purposes. However, the preservation of the defence heritage should be taken into consideration with a holistic approach. The new use should appropriate and respect to the authenticity of the heritage building.

The first step of the adaptive reuse process is to preserve the qualities of the defence heritage. In order to manage it, the number and the type of the visitors should be balance in a way to satisfy the residents and the tourist.

Secondly, it is important consider defence heritage buildings and structures as a part of the whole. It is important to understand the aim and method of constructing the defence used as observation towers that a panoramic view of the city can be seen. The castle should be connected to the axis on the coastal line.

Already functioned as museum. Some sections are used to exhibit the life in - period that the castle was constructed. The closed, open \& semi open esigner of the Disneyland is inspired from that castle. In this respect, this history can be reflected within the castle and the castle can be used for tourism purpose.

The castle is located on top of the mountains without any connection with the facilities.

The castle is located on top of the mountains without any connection with the city. Additionally, it is not easily accessible since it is located on a steep as trekking and climbing.

Already refunctioned as museum. Since the castle has an introverted rganization, its connection with the city is weak. The castle yard can be used to organize cultural activities $\&$ its connection with the city can be ensured.

The castle is partly demolished. It can be reconstructed and used as an exhibition center.

no enough documentation to reconstruct the castle.
Digital exhibition can be organized within the towers that the history of the tower for a panoramic view of the landscape.

Digital exhibition can be organized within the towers that the history of the tower for a panoramic view of the landscape.

Digital exhibition can be organized within the towers that the history of the tower for a panoramic view of the landscape. the history of the tower for a panoramic view of the landscape.

Digital exhibition can be organized within the towers that the history of the tower for a panoramic view of the landscape.

Historic ruins for visitors 
540. https://doi.org/10.3390/su11020540

[3] Misirlisoy, D., Günçe, K. (2016). Assessment of the adaptive reuse of castles as museums: Case of Cyprus. International Journal of Sustainable Development and Planning, 11(2): 147-159. https://doi.org/10.2495/SDPV11-N2-147-159

[4] Ashworth, G.J. (1990). Swords into ploughshares: Defence heritage tourism as the peaceful uses of the artefacts of war. Visions in Leisure and Business, 9(1): 7. https://scholarworks.bgsu.edu/visions/vol9/iss1/7

[5] Bernadz, L., Bajno, D. (2014). Remains of urban heritage defence structures- conservation, monitoring and reuse. SAHC2014 $9^{\mathrm{TH}}$ International conference on structural analysis of historical constructions, F. Pena and $\mathrm{M}$. Chavez (Eds.), Mexico City, Mexico, 14-17. https://doi.org/10.13140/2.1.4706.5609

[6] Viñals, M.J., Alonso-Monasterio, P., Martínez-Sanchis, I., Morant, M. (2016). New tourism uses for defence heritage: tourism enhancement of historic castle and fortresses. Managing the Environment, 35.

[7] Debeş, T. (2011). Cultural tourism: A neglected dimension of tourism industry. Anatolia, 22(2): 234-251.

[8] Timothy, D.J. (2014). Contemporary cultural heritage and tourism: Development issues and emerging trends. Public Archaeology, 13(1-3): 30-47. https://doi.org/10.1179/1465518714Z.00000000052

[9] Smith, M.K. (2009). Issues in Cultural Tourism Studies. Routledge.

[10] Timothy, D.J., Boyd, S.W. (2006). Heritage tourism in the 21st century: Valued traditions and new perspectives. Journal of Heritage Tourism, 1(1): 1-16. https://doi.org/10.1080/17438730608668462

[11] Timothy, D.J. (2011). Cultural Heritage and Tourism: An Introduction. Channel View Publications, 4.

[12] Giritlioğlu, İ., Ürün, A.C.Ş.T.B., Pazarlanması, O. (2010). Örnek Şehirler ve Türkiye'deki Şehirler Üzerine Öneriler. Adıyaman Üniversitesi Sosyal Bilimler Enstitüsü Dergisi, 3(4): 74-89.

[13] Göğebakan, Y. (2015). Dünya üzerindeki kültürel varlıkların turizme ve ekonomiye katkısı. Sanat ve Tasarım Dergisi, 5(2): 48-71. https://doi.org/10.20488/austd.13781

[14] Timothy, D.J., Nyaupane, G.P. (2009). Cultural Heritage and Tourism in the Developing world: A Regional Perspective. Routledge.

[15] Lussetyowati, T. (2015). Preservation and conservation through cultural heritage tourism. Case study: Musi Riverside Palembang. Procedia-Social and Behavioral Sciences, 184: 401-406. https://doi.org/10.1016/j.sbspro.2015.05.109

[16] Santa, E.D., Tiatco, S.A. (2019) Tourism, heritage and cultural performance: Developing a modality of heritage tourism. Tourism Management Perspectives, 31(31): 301-309. https://doi.org/10.1016/j.tmp.2019.06.001

[17] Poria, Y., Butler, R., Airey, D. (2003). The core of heritage tourism. Annals of Tourism Research, 30(1): 238-254.

[18] McKercher, B., Ho, P.S.Y. (2006). Assessing the tourism potential of smaller cultural and heritage attractions. Journal of Sustainable Tourism, 14(5): 473-488.

[19] Ho, P.S.Y., McKercher, B. (2004). Managing heritage resources as tourism products. Asia Pacific Journal of Tourism Research, 9(3): 255-266. https://doi.org/10.1080/1094166042000290655

[20] Jansen-Verbeke, M., Lievois, E. (1999). Analyzing heritage resources for urban tourism in European cities in D.G., Pearce \& R. W. Butler (eds). Contemporary Issues in Tourism Development, 81-107.

[21] Urry, J. (1990). The Tourist Gaze: Leisure and Travel in Contemporary Societies. London: Sage.

[22] Park, H.Y. (2014). Heritage Tourism. Routledge.

[23] Sonyel, S.R., Salahi, R.S. (2003). Cyprus: The destruction of a Republic and its aftermath (British documents 1960-1974). Cyrep, Lefkoşa.

[24] Tofallis, K. (2002). A History of Cyprus, London: Greek Institute.

[25] Günçe, K., Ertürk, Z., Ertürk, S. (2008). Questioning the "prototype dwellings" in the framework of Cyprus traditional architecture. Building and Environment, 43(5): 823-833. https://doi.org/10.1016/j.buildenv.2007.01.032

[26] Petre, J.S. (2010). Crusader castles of Cyprus: The fortifications of Cyprus under the Lusignans. Cardiff University (United Kingdom), 1191-1489.

[27] Kitchner, H.H. (1882). A triangulated survey of the island of Cyprus, Nicosia: Published by bank of Cyprus Cultural Foundation.

[28] URL1:http://www.cypnet.co.uk/ncyprus/city/kyrenia/ca stle/index.html, accessed in April 2021.

[29] Enlart, C. (1987). Gothic art and the renaissance in Cyprus. London: Trigraph.

[30] https://marycoons.files.wordpress.com/2015/03/fortlayout-diagram.jpg, accessed in January 2021.

[31] http://patrimundianorthcyprus.emonsite.com/pages/content/kantara-castle.html, accessed in January 2021.

[32] Jeffrey, G. (1983). A Description of the Historic Monuments of Cyprus. London: Zeno Publisher.

[33] Bağışkan, T. (2018). Kıbrıs'ın geçmişine yolculuk, Kıbrıs Türk Yazarlar Birliği Yayını, Lefkoşa.

[34] https://www.cyprushighlights.com/en/2014/12/06/xylof agou-venetian-watchtower/, accessed in January 2021.

[35] https://commons.wikimedia.org/wiki/File:A@a_o_pyrg os_tis_Rigenas_pervolia, accessed in January 2021. 